\title{
DISABILITY IN THE NATIONAL CENSUSES OF 2002 AND 2011 - A COMPARISON OF INFORMATION SCOPE $^{1}$
}

\begin{abstract}
Data on disability are collected in many statistical surveys, but the largest ones are censuses. The survey of disability based on census data in Poland has a long history dating back to 1921. During this period both the methodology of the survey and the scope of the data have been changing. The biggest modifications took place in 2011. NCP 2011 was the first census in Poland to be carried out by combing administrative data sources and the survey sampling method. The aim of the present study is to analyze and assess changes in the disability survey in NCP 2011 compared to NCP 2002 in terms of methodology and the scope of information.
\end{abstract}

Keywords: disability, population census 2002 and 2011 in Poland.

JEL: C18.

\section{INTRODUCTION}

The phenomenon of disability is regarded as one of the most serious social problems faced by the contemporary society. The number of people with disability is consistently rising, among others as a result of population aging. According to the latest WHO report, the phenomenon of disability affects over 1 billion people across the world, which accounts for about $15 \%$ of the world's population. Out of that total number, between 110 and 190 million adults experiences considerable limitations in activities of daily living. In addition, it is estimated that as many as 93 million children are affected by a mild to severe disability. This means that in the age group under 15 every 20th person suffers from this kind of health problem. The WHO report identifies factors which influence the diverse statistical picture of disability across countries, including different trends about health and environmental conditions, as well as factors such as road accidents, violence, natural disasters and military conflicts, bad

\footnotetext{
* Poznan University of Economics, Statistical Office in Poznań, g.dehnel@ue.poznan.pl

** Statistical Office in Poznań, t.klimanek@stat.gov.pl

1 The project is financed by the Polish National Science Centre, decision DEC2013/11/B/HS4/01472.
} 
nutritional habits and excessive consumption of alcohol and tobacco (WHO 2015: 2).

Tasks related to the possibly full inclusion of this social group in all kinds of activities, including social and occupational activities, are becoming an increasingly serious challenge for the world's societies. However their implementation, both at the national, regional and local level, requires detailed and up-to-date information. The need for data about disability, not only at the level of the country or provinces/ states but, above all, at the level of local territorial units, as well as expectations concerning their quality are expressed by different groups of data users.

At the national level the key users of information about disability are The National Advisory Council for Persons with Disabilities and The Government Plenipotentiary for Disabled People. According to the instruction included in $\S 3$ of the Charter of Rights of Persons with Disabilities, the Polish government is obliged to prepare information about initiatives undertaken each year to implement the rights of persons with disabilities set out in the resolution of the Polish parliament. To this end, the Government Plenipotentiary for Disabled People, authorised by the Minister of Labour and Social Policy, requests ministers and directors of central authorities to prepare and provide information about activities completed, continued or undertaken in a given year in order to implement the resolution of the Polish Parliament on 1 August 1997 - the Charter of Rights of Persons with Disabilities. The outcome of these activities is published as Information of the Polish Government about activities undertaken in a given year for the implementation of the provisions of the Charter of Rights of Persons with Disabilities of 1 August 1997 - the Charter of Rights of Persons with Disabilities. One of its most important elements are basic statistical data about disabled people, compiled on the basis of information collected in surveys conducted by the country's Central Statistical Office.

At lower levels of the country's territorial division the need for information about disability is voiced by local authorities of provinces and lower-level units (powiat) with a view to developing and implementing province-level programmes for the equalization of opportunities for persons with disabilities and combating social exclusion as well as providing assistance in the implementation of tasks related to employing disabled people, and local programmes for disabled people concerning social rehabilitation, occupational rehabilitation and employment and the observance of rights of persons with disabilities (Gąciarz, Rudnicki 2014: 260-266).

Other important users of statistical data about disability include members of the scientific community, who often express critical opinions concerning the scope and level of detail of data published by official statistics (Slany 2014: 44-62). 
National censuses are among the most important sources of knowledge about society, including people with disabilities, which provides a kind of portrait of the whole population at a given time. In addition, census results are the basis for estimating data about disability in intercensal periods. For this reason the scope and quality of census data cannot be overstated in modern societies. This article is an attempt at evaluating changes in the survey of disability that were introduced in the 2011 census (NSP 2011) in comparison with the census of 2002 (NSP 2002), both in terms of the survey methodology and the information scope.

\section{THE MODERN-DAY PERCEPTION OF DISABILITY}

Disability is a concept whose meaning changes to reflect the changing perception of this phenomenon. It is no longer understood only as a consequence of disease or injury. It is perceived, above all, in terms of various barriers that adisabled person encounters in society. Hence, the literature of the subject distinguishes two models of disability: a medical and a social model. The medical model treats problems encountered by a disabled person as a direct consequence of their disease or injury. The social model, on the other hand, is implied when disability appears as a result of limitations experienced by people affected by it, such as individual prejudice, limited access to public buildings, unadapted public transport, segregation in education, solutions on the labour market leading to the exclusion of disabled persons. Such a division is reflected by the perception of disabled people in surveys conducted by the Central Statistical Office, including in particular surveys carried out as part of censuses in 2002 and 2011.

Problems related to the understanding of the concept of disability already start at the level of definition. At present most European countries define disability in terms of barriers encountered by disabled people in their daily lives. The degree of disability is usually determined in terms of the decline in functional ability (from $20 \%$ to $100 \%$ ). Unfortunately, there no single definition of disability that would enable international comparisons. Moreover, in some countries there exist alternative definitions of "disability" that are used for different purposes, e.g. in social rehabilitation, occupational rehabilitation and employment, health care, education. What is more, just as there is no single definition of disability, so too each country has its own system of disability evaluation. For example, in Germany the degree of disability is determined according to a scale of functional decline, from $20 \%$ to $100 \%$. According to the German system, a person is classified as a severely disabled when the functional decline of the body is at least 50\%, regardless of consequences in the occupational sphere. In France, on the other hand, special committees 
established at the level of departments, distinguish three degrees of disability: light, moderate and severe. In Spain, it is disabled people's ability to work that is assessed to determine the degree of its decline. For purposes of employment, a person is regarded as disabled when their ability to work is impaired by at least $33 \%$. The number of people with disabilities published in documents depends on the definition of disability. For this reason, a person classified as disabled in one of EU member states, might not receive a disability status in another country. Comparisons of disability between different countries - even narrowed down to EU countries - are very limited. Statistics about the environment of disabled people in different EU countries are often hard to compare.

In Poland the legal definition of disability was established in 1997: according to the Act on Occupational and Social Rehabilitation and Employment of Persons with Disabilities (issued on 27.08.1997, Dz.U. ([Journal of Laws] of 2011, No. 127, item 721, as amended), the definition of a disabled person is formulated as follows:

"Disabled people are those whose physical, psychological or mental condition permanently or temporarily impairs, limits or prevents the performance of social roles, in particular when it limits their ability to perform their occupational duties." Until now several dozen amendments have been introduced into the Act - the last one in October 2015 - but the definition of a disabled person has remained unchanged.

The definition of disability adopted in official statistics for purposes of censuses reflects the considerations included in both models of disability. A person is classified as disabled when they have obtained a certificate issued an authorised body - persons considered legally disabled, or when they do not have a certificate but experience functional limitations in activities of daily living that are typical for their age (playing, studying, work, self-care) - persons considered only biologically disabled. The definitional scope of legal and biological disability can be illustrated using the following Venn diagram and data from 2011 census (GUS 2013).

Knowledge about disabled persons is significantly extended by their subjective assessment of ability to perform activities of daily living. Such assessment is important inasmuch as the official certificate of disability (even of the highest degree) does not always reflect limitations experienced in daily life.

Taking into account the subjective assessment of one's ability to perform basic activities of daily living that are typical for a given age, the population of legally disabled people was divided into 2 groups:

- people legally and biologically disabled, i.e. people with certificates of disability who reported (experienced) a completely or severely limited ability to perform basic activities,

- people with only legal disability, i.e. people with certificates of disability who did not report (experience) a limited ability to perform basic activities. 


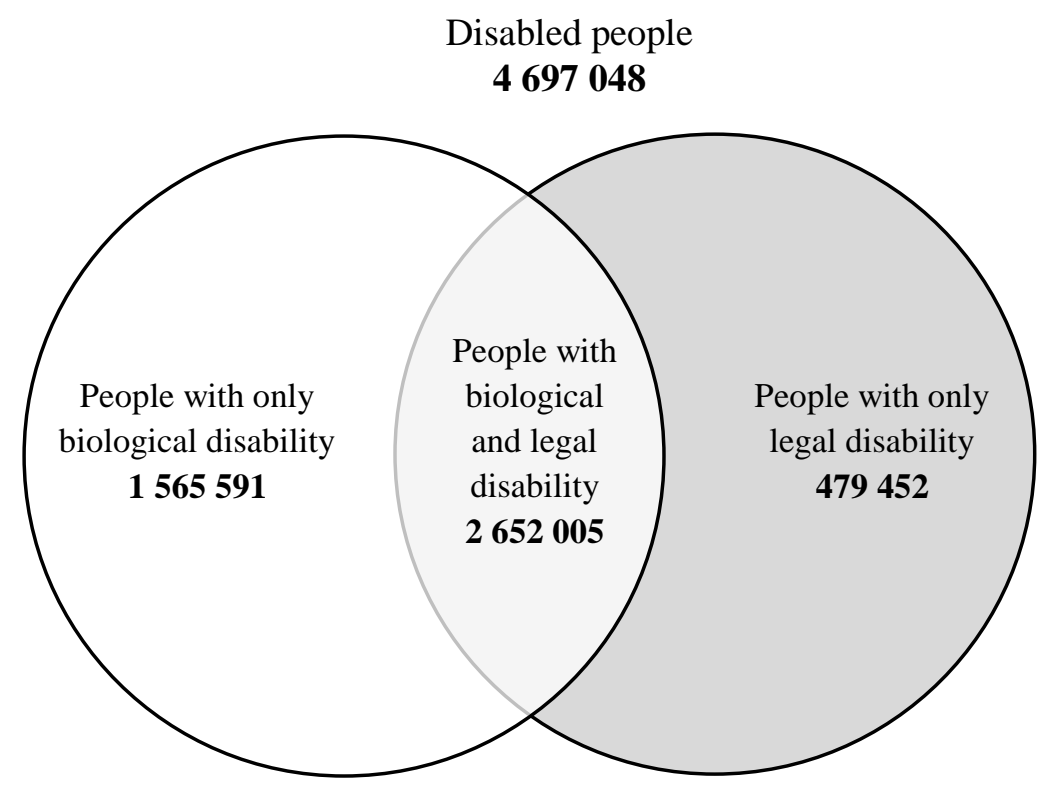

Figure 1. Decomposition of disabled people

Source: own elaboration based on GUS (2003).

Sometimes another classification is used: within the whole population of disabled people one distinguishes people according to the type and degree of functional limitations - regardless of whether they have a certificate of disability. The remaining group pf people, according to this classification, are regarded as disabled not experiencing limitations (people disabled only in the legal sense) (GUS 2013: 51).

It should be noted at this point that in other surveys conducted by official statistics (e.g. Labour Force Survey, the Z-06 survey) disabled people are identified exclusively on the legal basis, that is the fact of having an appropriate certificate.

\section{DISABILITY IN NATIONAL CENSUSES IN 20TH CENTURY}

The history of disability surveys in censuses in Poland in the 20th century dates back to 1921, which saw the first census after the restoration of Poland's independence (GUS 1927). The thematic scope of that census was impressive and one of its key objectives was to account for the demographic composition of the country facing the need to integrate different parts of its social fabric without 
prior knowledge about the population and its assets. In addition to demographic variables (sex, date of birth, marital status) questions in the census questionnaire asked for information about the place of birth, ethic characteristics (religious denomination, citizenship, mother tongue, nationality), literacy and the level of education, orphanhood among children under 16 and physical disability (deafness, muteness, blindness, limb loss) (GUS 1931). In this case the goal was to survey the problem of physical disability rather than disability in its broad sense, which was a reflection of the candidness and directness that characterised those times ${ }^{2}$. Initially, it had been suggested that this topic should be surveyed in the following census (Grossman 1920: 88-106). However, it was later retained with the addition of disability resulting from limb loss.
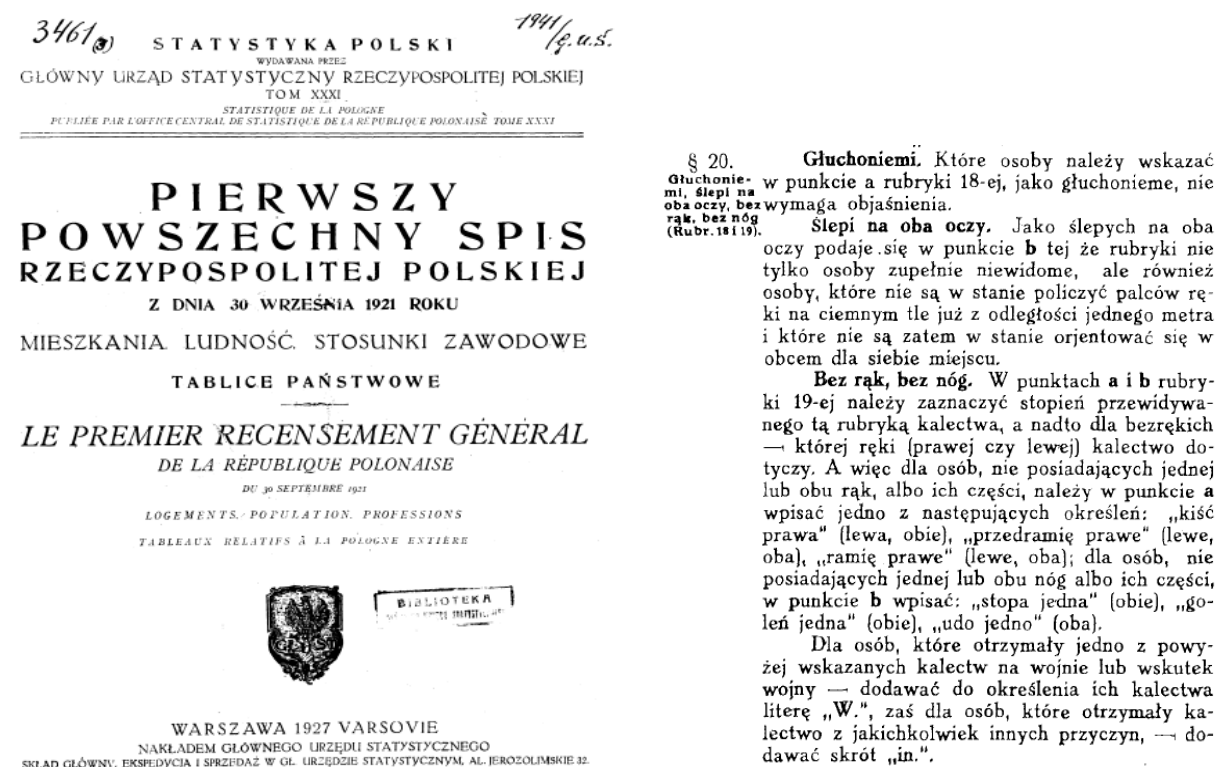

Figure 2. 1921 census forms and instructions - Poland

Source: Own elaboration based on GUS (1927); GUS (1931).

During the following censuses in Poland disability was not surveyed in 1931, 1946 (the first summary census after World War II), 1950, 1960, 1970 (Ulman 2012). The surveying of the problem of disability was resumed during the microcensus on 1974, which included question about legal invalidism - the term used for disability at that time. The census of 1978, was to first one to make

${ }^{2}$ Dz.U. z 1921 r. Nr 58, poz. 368 - Rozporządzenie Rady Ministrów z dnia 9 czerwca 1921 r. w sprawie przeprowadzenia powszechnego spisu ludności. 
a distinction between the two categories of disability, legal and biological. However, the term invalidism continued to be used. Legal invalids were defined as "people with a valid certificate issued by the Medical Committee for Invalidism and Employment (CIE) confirming invalidism and its group classification (I,II,III), regardless of whether or not they received a disability benefit." Biological invalids included people who declared they had, as a result of their disability or chronic disease, a limited capacity of performing basic activities typical for their age, such as studying, work, running the house. Two degrees of such a limitation were distinguished:

- complete limitation,

- partial limitation, i.e. disability, which significantly impairs the performance of basic activities. People with CIE certificates confirming legal invalidism did not always regard themselves as biological invalids, since sometimes their physical disability did not prevent them at all from performing their basic activities, e.g. highly qualified mental work. Persons who had declared biological invalidism were not necessarily legal invalids with a CIE certificate confirming their disability. Those two categories of invalidism are partly independent of each other ${ }^{3}$. The questions introduced in the census questionnaire at that time were used in subsequent censuses, which ensured relative comparability.

The emergence of the concept of disability understood as "invalidism", "impairment" or "handicap" was the consequence of the negative social perception of disability, viewed as a kind of deficiency, associated with a social stigma. Part of the criticism levelled at this approach was connected with its terminology - especially the notion of invalidism. The benefit of this view of disability, however, was the comprehensive perception of the relationship between the person and their environment, which accounted for the role played by social environment, above all, broadly understood barriers, both physical and mental, faced by a disabled person. In other words, the modern approach to disability was supposed to take into consideration not only a person's physical defects, functional limitations and health in the medical sense, but also unfavourable environmental conditions. One of the consequences of adopting this new approach in Poland was the appearance of the notion of "disability", also in official statistics in the 2002 census, which replaced the previous term "invalidism" (Bartkowski 2013: 15-16).

${ }^{3}$ Narodowy Spis Powszechny z dnia 7 XII 1978 r., Ludność Gospodarstwa Domowe Warunki Mieszkaniowe, Wojewódzki Urząd Statystyczny w Katowicach 1981 r., Silesian Digital Library, http://www.sbc.org.pl/dlibra/doccontent?id=98957\&from=FBC [Accessed 6.12.2015 r.]. 


\section{DISABILITY IN THE NATIONAL CENSUSES OF 2002 AND 2011 - A COMPARISON OF INFORMATION SCOPE}

The survey of disability in the 2002 census was different from those conducted in the previous censuses. It highlighted problems of disabled people confronted with phenomena previously unknown (before 1989 there was no record of unemployment in Poland and the working-age population was divided into occupationally active and passive population. The 2002 census was the first full enumeration of the population in which the term "invalidism" was substituted with "disability". The survey questionnaire contained 3 questions (12-14), which were to be answered, according to the general census principle, without submitting any documents to support the legal status. In the 2002 census, two degrees of disability were distinguished: complete and serious limitation of one's capacity to perform basic activities for one's age (studying, self-care, playing, etc.) as a result of disability or chronic disease. The methodology of the census made it possible to prepare detailed output tables for very detailed cross-classifications of spatial and thematic aggregations from the national to the local level (NUTS-5 units).

The 2011 census was conducted as a mixed mode census and was different from the classical, full enumeration of the population: data were partly obtained from administrative sources (registers and information systems), partly collected directly from individual respondents in a sample survey and partly in the socalled full enumeration survey. This aim of this solution was to reduce the cost of the census and the respondent burden while ensuring the high quality of census outputs. Data in the census were collected in thematic areas (modules) ${ }^{4}$.

It should be emphasized that all modules were implemented on the same $20 \%$ sample. As a result, each disabled person in a household which was included in the sample could be described in terms of characteristics specified in the other modules, e.g. information about a disabled person's level and area of education and acquired vocational education was stored in the module called "education", etc. One of the main challenges concerning the processing of census results was the fact that according to the Act on the National Census of Population and Dwellings in 2011 of 4.03.2010, answers to questions about disability were voluntary. This decision was made on account of the topic's sensitive character. The questions about disability were answered by respondents willing to participate; information about children was provided by their parents or legal guardians.

As a result of the voluntary nature of response to questions about disability, over 1.3 million respondents refused to answer any questions in the category.

\footnotetext{
${ }^{4}$ http://stat.gov.pl/spisy-powszechne/nsp-2011/z-jakich-tematow-byly-zbierane-dane/
} 
It can be assumed that some of those who refused were disabled people. More refusals came from female respondents, who accounted for $52 \%$ of that group and from city dwellers (58.5\%). Classified by economic group, refusals reveal another interesting pattern: over 50\% of women who refused to answer were in the working age group, while the share of men in this age group was much larger and exceeded $70 \%$. In the post-working age group, refusals to answer question on disability were much more common among women (36.3\%) than among men (16.7\%).

Table 1. A comparison of the scope of questions on disability in the questionnaires in the 2002 and 2011 censuses.

\begin{tabular}{|c|c|}
\hline NSP 2002 & NSP 2011 \\
\hline 1 & 2 \\
\hline \multirow[t]{3}{*}{$\begin{array}{l}\text { Are you completely or seriously limited in } \\
\text { your ability to perform basic activities typical } \\
\text { for your age (working, studying, self-care, } \\
\text { playing, etc.) as a result of disability or a } \\
\text { chronic disease? } \\
\text { - yes, completely } \\
\text { - yes, seriously } \\
\text { - no }\end{array}$} & $\begin{array}{l}\text { Have you experienced, as a result of your health } \\
\text { problems (disability or chronic disease) any } \\
\text { limitations in your ability to perform basic } \\
\text { activities typical for your age (attending school, } \\
\text { working at your job, running the house, taking care } \\
\text { of yourself) for at least } 6 \text { months } \\
\text { - yes, completely limited } \\
\text { - yes, seriously limited } \\
\text { - yes, moderately limited } \\
\text { - no, I don't experience any limitations } \\
\text { - I do not want to answer this question }\end{array}$ \\
\hline & $\begin{array}{l}\text { How long have you experienced limitations in } \\
\text { your ability to perform typical activities? } \\
\text { - from } 6 \text { months to } 1 \text { year } \\
\text { - from } 1 \text { to } 5 \text { years } \\
\text { - from } 5 \text { to } 10 \text { years } \\
\text { - I do noars or longer } \\
\end{array}$ \\
\hline & $\begin{array}{l}\text { Please state the reason why you experience } \\
\text { limitations in your ability to perform typical } \\
\text { activities: (select no more than } 3 \text { answers) } \\
\text { - defects and diseases of the musculoskeletal } \\
\text { system, the visual organ, the hearing organ, } \\
\text { cardiovascular disorders, neurological disorders, } \\
\text { other disorders; } \\
\text { - I do not want to answer this question }\end{array}$ \\
\hline $\begin{array}{l}\text { Have you got a valid certificate of disability } \\
\text { issued by a relevant evaluation body } \\
\text { invalidism or (in the case of children under } \\
\text { 16) are you entitled to receive an attendance } \\
\text { allowance? } \\
\text { - yes } \\
\text { - no }\end{array}$ & $\begin{array}{l}\text { Have you got a valid certificate confirming } \\
\text { disability, inability to work or the status of } \\
\text { invalidism? } \\
\text { - yes } \\
\text { - no } \\
\text { - I do not want to answer this question }\end{array}$ \\
\hline
\end{tabular}


Table 1 (cont.)

\begin{tabular}{|c|c|}
\hline 1 & 2 \\
\hline $\begin{array}{l}\text { How was this inability to work/disability/ } \\
\text { invalidism classified? } \\
\text { - Group I of invalidism or a severe disability } \\
\text { or complete inability to work and } \\
\text { independent life or inability to work in an } \\
\text { agricultural holding with an entitlement to } \\
\text { an attendance allowance. } \\
\text { - Group II of invalidism or a moderate } \\
\text { disability or complete inability to work, } \\
\text { or paup III of invalidism or a light disability } \\
\text { work in an agricultity to work or inability to holding or the need } \\
\text { to retrain }\end{array}$ & $\begin{array}{l}\text { How was this inability to work/disability/ } \\
\text { invalidism classified? } \\
\text { - Group I of invalidism or a severe disability or } \\
\text { complete inability to work and independent life } \\
\text { or inability to work in an agricultural holding } \\
\text { with an entitlement to an attendance allowance. } \\
\text { - Group II of invalidism or a moderate disability } \\
\text { or complete inability to work, } \\
\text { - Group III of invalidism or a light disability or a } \\
\text { partial inability to work or a long-term inability } \\
\text { to work in an agricultural holding without an } \\
\text { entitlement to an attendance allowance or the } \\
\text { need to retrain } \\
\text { - disability for persons under 16, } \\
\text { - I do not want to answer this question }\end{array}$ \\
\hline
\end{tabular}

Source: Own elaboration based on questionnaires from the 2002 and 2011 censuses, GUS (2013).

There is no doubt that the quality of census data may have been by a large number of people from whom no detailed information (also in other modules) was collected as a result of their stay abroad for at least 12 months.

Table 2. Basic characteristics of disability in the censuses of 2002 and 2011

\begin{tabular}{|l|r|r|}
\hline \multicolumn{1}{|c|}{ Years } & 2002 & 2011 \\
\hline DISABLED PEOPLE & 5457 & 4697 \\
\hline per 1000 inhabitants & 143 & 122 \\
\hline LEGALLY & 4450 & 3131 \\
\hline aged 16 or older with & 4315 & 2997 \\
\hline severe disability & 1065 & 892 \\
\hline moderate disability & 1427 & 1190 \\
\hline light disability & 1572 & 802 \\
\hline Unspecified & 252 & 110 \\
\hline aged 16 or over with a disability certificate & 135 & 135 \\
\hline ONLY BIOLOGICALLY & 1007 & 1566 \\
\hline
\end{tabular}

Source: own elaboration based on census data, GUS (2013).

According to the 2011 census, people with disabilities accounted for $12.2 \%$ of the population, while the 2002 census put that figure at $14.4 \%$. It should be noted that as a result of refusals, the percentage of disabled people in relation to 
the total number of people may be considerably underestimated. Another interesting development emerging from the data is a decline in the number of legally disabled people; a reverse trend can be observed for only biologically disabled. Most disabled people had a certificate of disability (2002 - 81.6\%, $2011-66.7 \%)$. The changes observed between the censuses could be explained by the introduction of stricter criteria of awarding disability and attendance benefits to applicants and the decision not to apply for benefit entitlements at the start of retirement. Another change is an increase in the percentage of people with severe or moderate disability, accompanied by a considerable decline in the number of people with light disability.

During NSP2011, the Central Statistical Office referred to a number of administrative registers containing information on disability/inability to work, which was used for purposes of official statistics (by virtue of the Act on the 2011 Census) The following registers were used:

- Social Insurance Institution (ZUS)

- The Agricultural Social Insurance Fund

- The Central Registry of Insured Persons

- State Fund for Rehabilitation of Disabled Persons (PFRON)

- Powiat Employment Offices (registers of the unemployed and job seekers)

- Powiat Committees for the Evaluation of Disability (EKSMOoN)

- gmina authorities (systems of social care, systems of family benefits).

Respondents who refused to answer questions about functional limitations but confirmed the fact of having a valid disability certificate, were assigned a degree of disability based on the status in the ZUS register. In the case of missing data, the same procedure was applied for the EKSMOoN register.

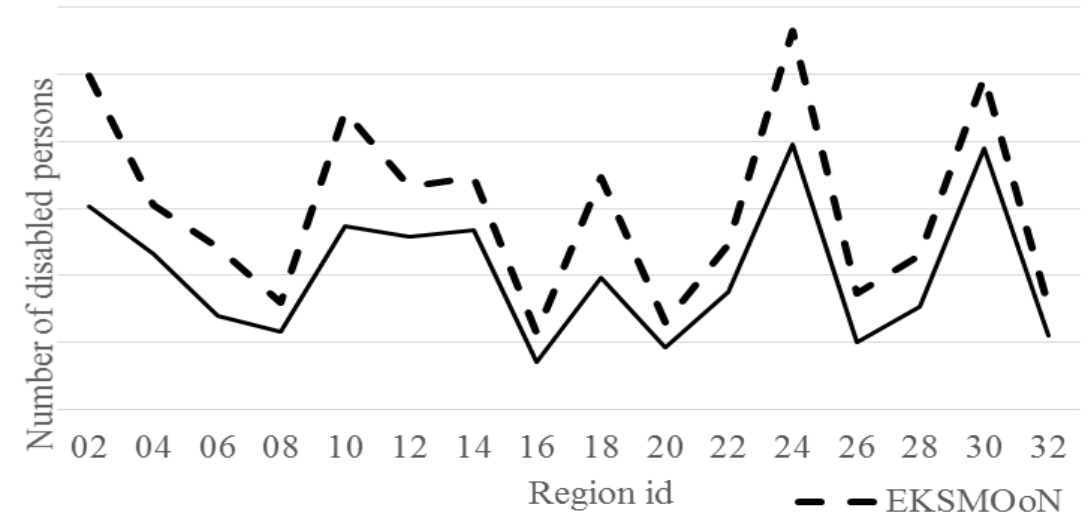

Figure 3. Light degree of disability - EKSMOon and ZUS registers comparison Source: own elaboration based on census data. 


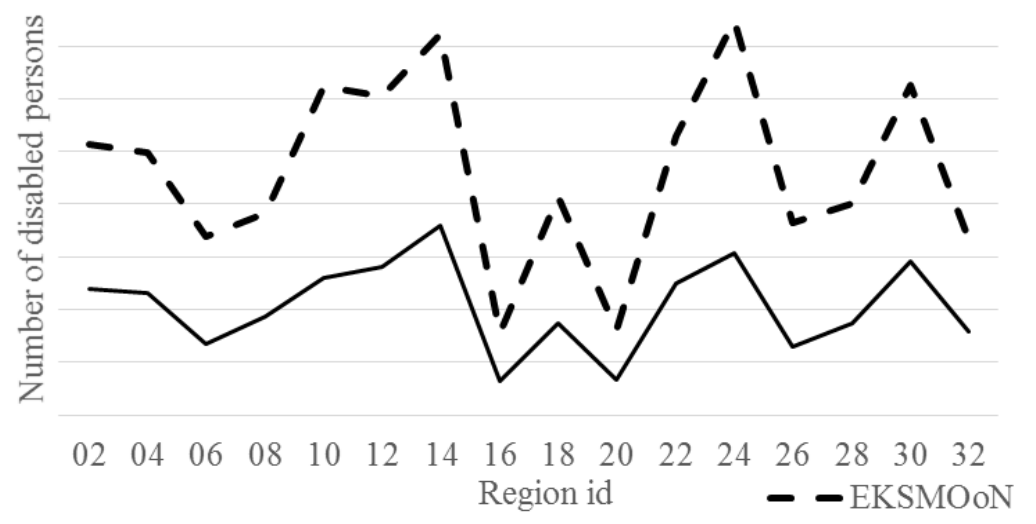

Figure 4. Moderate degree of disability - EKSMOon and ZUS registers comparison Source: own elaboration based on census data.

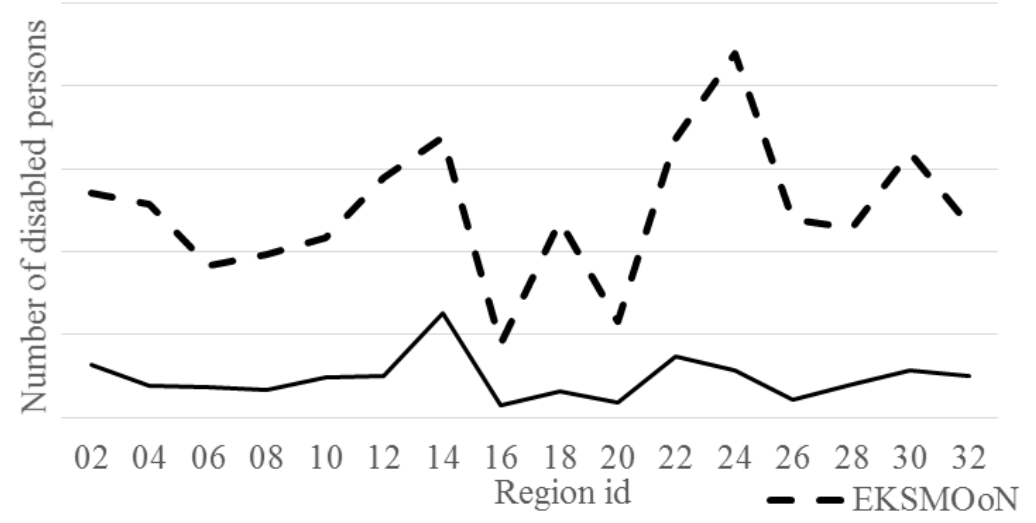

Figure 5. Severe degree of disability - EKSMOon and ZUS registers comparison

Source: own elaboration based on census data.

From the viewpoint of quality, it is interesting to analyse the compatibility between the ZUS and EKSMOoN registers in terms of the degree of disability. Distribution curves for each province are similar, but it can be noticed that the compatibility between the two registers decreases with increasing degree of disability. The diagrams below show a comparison by province, but it should be noted that similar patterns can be observed at the level of powiat (NUTS 4) and gmina (NUTS 5) (although this pattern can sometimes be disturbed by the impact of randomness). 
A detailed quality analysis of register data used in the 2011 census should take into account the following elements:

- possible definitional differences (ZUS certifies one's inability to work, which is closely related to the possibility of obtaining an entitlement to a disability benefit. It should be remembered that inability to work is a much narrower concept than disability, which is evaluated by county committees for the evaluation of disability,

- duplicates - the same person has multiple entries in different registers (the Polish law allows the existence of certificates issued by different institutions). Despite the equivalence of certificates issued for purposes of disability and other benefits, in some situations having both is desirable: certificates are issued independently and can be valid for different periods; the fact of having two certificates significantly decreases the risk of losing discounts and benefits while one is awaiting another evaluation),

- temporal compatibility and validity (people may have certificate with indefinite validity, i.e. those that were issued before 31 December 1997 regardless of whether they were evaluations issued by sectoral, agricultural committees or the ZUS Medical Committee for Invalidism and Employment People with certificates issued after 1 January 1998 are regarded as disabled only when they have a valid certification of inability to work issued by ZUS or an evaluation certifying the degree of disability or disability (for children under 16) issued by committees for the evaluation of disability. At present both ZUS and PZOnN issue certificates with limited validity ranging from 1 to 5 years.

\section{SUMMARY}

Trends observed in censuses conducted by national statistical institutes at the forefront of modern statistical methodology indicate a departure from classical methods of data collection in full enumeration surveys involving census takers making personal contact with all individuals of a given population. In the case of disability surveys conducted as part of the 2011 census, the information scope of data contained in registers held by ZUS, KRUS, PFRON and the National System for Monitoring Disability Evaluation (EKSMON) seems to surpass the amount of information that was collected in previous censuses. It can be hoped that legal statuses recorded in registers will turn out to be a more reliable and precise source of information than declarative legal statuses, often reported on behalf of those concerned. So far the practice of relying on "proxy reports" provided by one household member about the other members has led to significant bias in censuses as a result of systematic errors (Paradysz 2010: 53). For this reason a wider use of administrative registers is recommended. It should 
be noted that the mixed mode method adopted for the 2011 census (including the use of registers) made it possible to, first of all, largely overcome the problem resulting from the Act on the 2011 Census of 4 March 2010 about the voluntary nature of response, and secondly, helped to considerably decrease the respondent burden by using information which was already stored in databases held by different agencies of central and local government. Another important fact is that the scope of registered information considerably expands the body of knowledge about legal disability assuming that the completeness of databases maintained by public administration improves with increasing legal sanctions or incentives that are related to the fact of registration (of persons, families or companies) - the participation in the disability benefit system or the system of other benefits and discounts (e.g. attendance benefits, Blue Badge parking permits, etc.), the use of possibly most complete information enables the creation of output tables for this category of disability for practically any cross-classification, where the level of detail can only be limited by the obligation to ensure statistical confidentiality.

Undoubtedly further work on bringing administrative registers up to the standard required for statistical purposes, initiated in the 2011 census, should be continued and developed (removing definitional differences and duplicates, improving temporal equivalence and validity); the biggest challenge for future censuses will be surveying the population of people classified as only biologically disabled. The work of the Central Statistical Office has been greatly facilitated by the amended act on public statistics, which in Article 35b Paragraph 1. subparagraph 18 authorizes public statistics to process for statistical purposes personal data about the degree of inability to work, disability certification, the degree of disability.

Owing to imprecise definitions, methodological issues discussed above (the sensitive nature of questions about biological disability, the voluntary character of responding), as well as the lack of information about disability defined in this sense in administrative registers, it is difficult to estimate this category of disability at a required level of territorial aggregation based on a sample survey; for this reason it is reasonable to consider the possibility of using non-classical methods, such as small area estimation. The key and most challenging element of estimating only biological disability will be the selection of auxiliary variables at the level of units, areas or domains for which estimates are expected.

\section{REFERENCES}

Bartkowski J. (2013), Położenie społeczno-ekonomiczne osób niepetnosprawnych $w$ Polsce. Raport ekspercki na podstawie danych zastanych i najnowszych badań, Raport przygotowany w ramach projektu „Od kompleksowej diagnozy sytuacji osób niepełnosprawnych w Polsce do nowego modelu polityki społecznej wobec niepełnosprawności”, Kraków, Akademia Górniczo-Hutnicza im. Stanisława Staszica. Niepublikowany manuskrypt. 
Gąciarz B. (red), Rudnicki, S. (2014), Polscy niepetnosprawni. Od kompleksowej diagnozy do nowego modelu polityki społecznej, Wydawnictwa AGH Kraków.

Grossman H. (1920), Znaczenie i zadania pierwszego powszechnego spisu ludności w Polsce, „Miesięcznik Statystyczny”, t. 1, z. 1-3, s. 88-106. Przedruk w Spisy ludności Rzeczpospolitej Polskiej 1921-2002, GUS, Warszawa 2002, s. 98-113.

GUS (1927), Pierwszy Powszechny Spis Rzeczypospolitej Polskiej z dnia 30 września 1921 roku, Mieszkania, Ludność, Stosunki zawodowe. Tablice państwowe, Warszawa.

GUS (1931), Pierwszy Powszechny Spis Rzeczypospolitej Polskiej z dnia 30 września 1921 roku. Formularze i instrukcje spisowe, Warszawa.

GUS (2003), Osoby Niepetnosprawne oraz ich Gospodarstwa Domowe 2002. Część I. Osoby Niepetnosprawne, NSP 2002, Warszawa.

GUS (2013), NSP, 2011, Z jakich tematów byly zbierane dane, Internet site: http://stat.gov.pl/ powszechne/nsp-2011/z-jakich-tematow-byly-zbierane-dane/, [Access: 2.12.2015].

GUS (2013), Ludność i gospodarstwa domowe. Stan i struktura społeczno-ekonomiczna. Część I. Ludność. NSP 2011, Warszawa.

Narodowy Spis Powszechny z dnia 7 XII 1978 r., Ludność Gospodarstwa Domowe Warunki Mieszkaniowe, Wojewódzki Urząd Statystyczny w Katowicach 1981 r., Śląska Biblioteka Cyfrowa, Internet site: http://www.sbc.org.pl/dlibra/doccontent?id=98957\&from=FBC, [Access: 6.12.2015].

Paradysz J. (2010), Konieczność estymacji pośredniej w spisach powszechnych. [w:] E. Gołata (red.) Pomiar i informacja $w$ gospodarce, Wyd. Uniwersytetu Ekonomicznego w Poznaniu, Poznań, ZN. 149, s. 45-66.

Slany K. (2014), Osoby niepetnosprawne w świetle Narodowego Spisu Powszechnego Ludności i Mieszkań z 2011 r. - wybrane aspekty, [w:] Niepełnosprawność - zagadnienia, problemy, rozwiązania, nr II/2014(11), Uniwersytet Jagielloński w Krakowie, Akademia GórniczoHutnicza w Krakowie.

Ulman P. (2012), Problematyka niepetnosprawności w badaniach statystycznych, „Wiadomości Statystyczne", R. 57, nr 1, GUS, Warszawa.

WHO global disability action plan 2014-2021: better health for all people with disability, Internet site: http://apps.who.int/iris/bitstream/10665/199544/1/9789241509619_eng.pdf, [Access: 2.12.2015].

\section{Grażyna Dehnel, Tomasz Klimanek}

\section{NIEPELNOSPRAWNOŚĆ W NARODOWYCH SPISACH POWSZECHNYCH 2002 I 2011 - PORÓWNANIE ZAKRESU INFORMACYJNEGO}

Streszczenie. Dane dotyczące osób niepełnosprawnych pozyskiwane są w wielu badaniach statystycznych, jednak największym badaniem są spisy powszechne. Temat niepełnosprawności w spisach polskich ma swoją długą historię sięgającą 1921 roku. W ciągu tego okresu zmieniała się zarówno metodyka badania, jak i zakres przedmiotowy danych. Największe zmiany nastąpiły w 2011 roku. NSP 2011 był po raz pierwszy w Polsce przeprowadzony z wykorzystaniem administracyjnych źródeł danych oraz metody reprezentacyjnej. Celem niniejszego referatu jest analiza i ocena zmian w badaniu niepełnosprawności jakie nastąpiły w NSP2011 w porównaniu z NSP2002 zarówno co do metody badania, jak i zakresu informacyjnego.

Słowa kluczowe: niepełnosprawność, spisy powszechne ludności w Polsce w 2002 i 2011 r. JCL: C18. 